\title{
Chemical Composition of Ulvaria oxysperma (Kützing) Bliding, Ulva lactuca (Linnaeus) and Ulva fascita (Delile)
}

\author{
Márcia de Pádua, Paulo Sérgio Growoski Fontoura and Alvaro Luiz Mathias* \\ Departamento de Engenharia Química; Universidade Federal do Paraná; mar_padua@hotmail.com.; \\ fontoura@engquim.ufpr.br; mathias@ufpr.br; C.P.19011;81531-990; Curitiba - PR - Brazil
}

\begin{abstract}
Chemical composition of three species of Chlorophyta, Ulva lactuca, Ulva fasciata and Ulvaria oxysperma, was determined. Ulvaria oxysperma showed humidity (16-20\%), ash (17-31\% dry-base), proteins (6-10\%db), lipids $(0.5-3.2 \% \mathrm{db})$, fibers $(3-12 \% \mathrm{db})$ and carbohydrates $(46-72 \% \mathrm{db})$ which corresponded to $192-270 \mathrm{kcal}^{.100 \mathrm{~g}^{-1}}$ (wetbase). U lactuca (15-18\%db) and U fasciata (13-16\%db) revealed grades slightly higher for proteins, but with similar energetic contents (250-272 and 225-239 $\left.\mathrm{kcal} 100 \mathrm{~g}^{-1}\right)$, respectively. Natural blades of $U$ lactuca and of $U$ fasciata were more rigid than blades of U oxysperma. Other native algae showed higher protein levels. Ulvaria sp could be cultivated on the cotton-nylon net without having significance competition from other algae or predators degradation. On the other hand, it was essential choose a place without destructive tide action. Cultivated Ulvaria sp showed similar chemical composition as that grown on natural substrates.
\end{abstract}

Key words: Chemical composition, algae, Ulvaria, Ulva, Guaraqueçaba, Ilha do Mel

\section{INTRODUCTION}

Oceanic algae are vegetables without vascular system; however, its cells can form agglomerations, as strings or blades. Algae can be applied to obtain several products. It is possible to classify algae in three groups of color: Chlorophyta (green), Phaeophyta (brown) and Rhodophyta (red). Mahasneh et al. (1995) found antibiotic activities in the three groups of algae, which supported the importance of these vegetables. Chlorophyta are commonly used as food due to high contents of vitamins and minerals. Phaeophyta are typical suppliers of alginic acid. Rhodophyta are responsible to produce agar-agar and carragenan. These polymers are used to improve the chemical and physical characteristics of several industrial products (Jarrouj, 1992, Miller and Blunt, 2000, Pal et al., 1998).

Ulvaria oxysperma and Ulva spp are Chlorophyta. These species are different by number of cell strata. After a transversal cut, Ulva genus shows two stratum of cells, while Ulvaria has only one stratum (Joly, 1965). Ulvaria oxysperma lives frequently in mangroves over mud or roots, stems of tree and stones. Ulva fasciata prefers stones as substratum, while Ulva lactuca prefers mangroves and sand (Joly, 1957).

Ulvaria sp and Ulva spp grow abundantly in the seaside of the Paraná State. Ulva lactuca grows in Guaraqueçaba and Ulva fasciata grows in Ilha do Mel, while Ulvaria oxysperma grows into the two ecosystems (Shirata, 1993). U. oxysperma is harvested by the inhabitants from Guaraqueçaba to improve the domestic budget.

*Author for correspondence 
$U$. oxysperma is harvested by hand, dried at room temperature, and wrapped into plastic packages commercial purposes. However, there are physical, chemical and biological studies of environment were these algae no exist. It is necessary to preserve this ecosystem (Borges, 1992; Ipardes, 1990; Soares, 1990).

Chemical composition of some species of sea algae from India was studied. Enteromorpha linza, E. prolifera, Caulerpa taxifolia, Sargassum johnstonii and Ulva fasciata were studied to evaluated in nutritional quality. Ulva fasciata showed high concentration of lipids, normal levels of fiber and low proportion of protein (Naidu et al., 1993). Arieli et al. (1993) evaluated the nutritional value of Ulva lactuca as food for ruminants. Algae were produced from an integrated marine culture project using six FinnMerino crossbred ram lambs. Ulva lactuca was characterized as low-energy high-nitrogen foodstuff, but it is considered a good food for ruminants.

Specific nutritional evaluation of sea algae about amino acids content has been considered recently. Seventeen of the essential amino acids were detected in hydrolyzed protein in eighteen species of algae, including Ulva lactuca. There were significant variations in composition of amino acids for the different genus of algae. On the other hand, low variation was observed in total nitrogen and inorganic contents (Qasim, 1991).

Soluble and insoluble dietary fiber contents of marine algae: wakame (Undaria pinnatifida), hijiki (Hijiki fusiformes), sea spaghetti (Himanthalia elongata), aroma (Eisenia bicylis), sea lettuce (Ulva lactuca), nori (Enteromorpha spp) and nori (Porphira tenera) were estimated by the gravimetric method. Dietary fiber contents were between 32.7 and $74.6 \%$ (on a dry weigh basis) of which 51.6 to $85.0 \%$ were water soluble. These marine algae have are good suppliers in fibers, which shown to have chemical, physicochemical and rheological diversities that may be beneficial in nutrition (Lahaye, 1991). Lahaye and Axelos (1993) suggested that Ulva spp is a good source of gelling polysaccharides of potential economic value. Water-soluble polysaccharides were extracted from Ulva spp which proliferate along Brittany shores of France. They were composed of the combination of rhamnose, glucose, xylose, mannose, galactose, uronic acid and sulfate group. Mechanisms for gel formation were proposed, which unusually involve both boron and calcium ions.

Ivanova et al. (1994) isolated a polysaccharide with antiviral effect from Ulva lactuca. This polysaccharide contains arabinose, xylose, rhamnose, galactose, manose and glucose (1:1:9:5:2:5:16), besides another unidentified sugar. Antiviral activity in vitro against human and avian influenza virus was identified. This property was dose-dependent, strain-specific and selective.

Serot et al. (1994) studied the extraction and the characterization of proteins from Ulva spp to increase the commercial profit. Extraction was performed according to an experimental design involving extraction time (60 to $300 \mathrm{~min}$ ), amount of dry algae (1 to 2:100, w:v) and $\mathrm{NaOH}$ solution $\left(0.5\right.$ to 2 mol. $\left.\mathrm{dm}^{-3}\right)$. Optimal extraction condition was obtained after $200 \mathrm{~min}$ extraction to $1 \mathrm{~g}$ of dry algae in $100 \mathrm{~mL}$ of $2 \mathrm{~mol} . \mathrm{dm}^{-3} \mathrm{NaOH}$ solution. $46.6 \%$ of crude protein were extracted and a significant amount of non-dialyzable polypeptides too. Molecular weight reveled four major bands $(12,400, \quad 18,000,20,500,21,700)$ for the polyacrylamide gel electrophoresis method and three peaks $(100,000,60,000$, and 25,000) for the permeation gel chromatography.

Excess nutrients from coastal fish farms produce water pollution. Ulva $\mathrm{sp}$ was cultivated in the polyculture of seaweed and fish in order to reduce eutrophication in the sea. The growth of Ulva was closely related to the water temperature and the optimum value is between 20 and $28{ }^{\circ} \mathrm{C}$ (Hirata and Kohirata, 1993).

Ulvaria oxysperma is the new name to Monostroma oxysperma. This alga is less studied than Ulva spp, although it is more used as human food. $U$. oxysperma is more pleasant to sense of taste than Ulva spp. Guo and Matthieson (1992) studied the seasonal distribution of $U$. oxysperma in the estuary of Northeast of "New England" (USA). The growth of $U$. oxysperma and the economical viability to large production was studied for Kapraun and Sherman (1989).

Cordeiro-Marino et al. (1993) studied life-history and ontogeny for ulvaceous from State of Espírito Santo, Brazil. Three levels of salinity $(1,20$ and $\left.40 \mathrm{~g} \cdot \mathrm{dm}^{-3}\right)$ and four levels of temperature $(15,20$, 25 and $30^{\circ} \mathrm{C}$ ) were tested in factorial design to evaluate the maximum growth rate to one of the population of Ulvaria sp. The maximum growth was to $25^{\circ} \mathrm{C}$ and $40 \mathrm{~g} \cdot \mathrm{dm}^{-3}$ and the smaller growth 
was to $30^{\circ} \mathrm{C}$ and 1 g. $\mathrm{dm}^{-3}$. Algae died after 54 to 73 days with a combination of $30^{\circ} \mathrm{C}$ and 1 g. $\mathrm{dm}^{-3}$. Ulvaria sp does not grow at $15^{\circ} \mathrm{C}$ in any salinity or in $30^{\circ} \mathrm{C}$ and $1 \mathrm{~g} . \mathrm{dm}^{-3}$.

The objective of this work was characterize the chemical composition of Ulva spp and Ulvaria oxysperma found in the Paraná State. Some of these results were compared to other algae species and cultivated Ulvaria sp.

\section{MATERIALS AND METHODS}

\section{1 - Harvest and manipulation of algae from natural substrate}

Harvest was pre-determined by the Nautical Cards from DRH (Diretoria de Hidrografia e Navegação) to coincide with low tide period, to permit a large area to harvest, which was generally in the morning. The species studied were harvested on the mangrove of the Caetê, in the Bay of Guaraqueçaba (latitude $25^{\circ} 15^{\prime}-25^{\circ} 20^{\prime}$ South and longitude $48^{\circ} 20^{\prime}-48^{\circ} 25^{\prime}$ West) and Saco do Limoeiro, Ilha do Mel, Bay of Paranaguá (latitude $25^{\circ} 33^{\prime}-25^{\circ} 34^{\prime}$ - South - longitude $48^{\circ} 18^{\prime}-48^{\circ} 19^{\prime}$ West). These two locality belong to Complexo Lagunar de Iguape - Bay of Paranaguá.

The samples were obtained from June 1995 to February 1996. The harvest was manual and sometimes with a stainless knife to untie the algae from soil or stone. Algae were put into plastic packages to carry to the laboratory, and were cleaned under water in the laboratory to remove of particles in suspension and adhered. After that, the algae were dried at room temperature, without direct light of sun.

Dry algae were packaged in paper, identified and stored in cardboard boxes in laboratory to process and analysis. The specie was identified using the Analytical Keys of Joly (Joly 1957 and 1965) and Ugadim (1973). Parts of the material were registered as droughty samples on the HPUC (Herbarium of the Pontificia Universidade Católica do Paraná, PUC-PR).

\section{2 - Cultivation of Ulvaria oxysperma}

Cotton-nylon nets with 0.7 by $3 \mathrm{~m}$ were installed from 1997 to 1999 in the Ilha do Barbado in Guaraqueçaba to evaluate: a) adhesion capacity; b) competition with others algae; c) presence of predators; d) resistance of tide and e) physical (wet and dried algae) and chemical (residual humidity, ash, protein, carbohydrate, fat and fibers) characteristics. Nets were put them above the water levels similar the height found natural $U$. oxysperma. This way, part of time algae on the net was above and other time was below of water.

\section{3 - Analysis}

\section{A - Samples Preparation}

Samples were dried at room temperature in darkness. Alternatively, some samples were dried in an OLIDEF oven (model CZ) at $50{ }^{\circ} \mathrm{C}$ to compare the effects of the industrial technique. The samples were identified by genus and harvest localization and stored in Kraft paper packages. 10 to $15 \mathrm{~g}$ of alga was weighed in analytic balance (METTLER H6, $0.1 \mathrm{mg}$ ) for assays.

\section{B - Humidity and Ash}

Humidity was considered as the losses in mass from a sample $(1 \mathrm{~g})$ after drying at $100^{\circ} \mathrm{C} \pm 2^{\circ} \mathrm{C}$ (ELEKTROHELIOS oven J84234-2, 200 ${ }^{\circ} \mathrm{C}$ ). The residual mass in this sample was heated at $600^{\circ} \mathrm{C}$ $\pm 10^{\circ} \mathrm{C}$ (FORNITEC $0159,1200^{\circ} \mathrm{C}$ ) to obtain ash.

\section{C - Organic Material}

It was calculated through the difference between $100 \%$ and the sum of humidity and ash values.

\section{D - Nitrogen and Protein}

Nitrogen was measured by Kjeldahl method using the distiller-digester PROCION (110V, Brazil) (Yokoyama and Guimarães, 1975).

\section{E - Lipids or Ethereal Extract}

2 to $5 \mathrm{~g}$ of sample were extracted with ethyl ether in Soxhlet for 5 hours. The solvent was evaporated and the residual mass on the balloon was considered lipids.

\section{F - Fibers}

2 to $5 \mathrm{~g}$ of sample were digested with $200 \mathrm{~cm}^{-3}$ of $5 \% \mathrm{HCl}$ for 30 minutes. The mixture was filtrated and washed with hot water. The residue was digested with $200 \mathrm{~cm}^{-3}$ of $5 \% \mathrm{NaOH}$ under reflux to 30 minutes. The mixture was filtered and washed with water until negative alkaline reaction with indicative paper (methyl red). The material was washed with $20 \mathrm{~cm}^{-3}$ of ethyl alcohol and with $20 \mathrm{~cm}^{-3}$ of ethyl ether. The residue was dried at $100^{\circ} \mathrm{C}$ by two hours and the residual mass was considered fibers. 


\section{G - Carbohydrate}

Subtraction of the sum of humidity, protein, lipids, fibers and ash values from 100 was the carbohydrate contents in percentage.

\section{H - Calories}

Calories was calculated by the following equation: Calories $\left(\mathrm{kcal} 100 \mathrm{~g}^{-1}\right)=4$ - protein $(\%)+9$ • lipids $(\%)+4 \bullet$ carbohydrate $(\%)$.

Ash, organic material, protein, lipids, fiber, carbohydrate grades were expressed as dry base $(\mathrm{db})$, but calories was expressed as wet base.

\section{RESULTS AND DISCUSSION}

\section{1 - Physical aspects}

Ulva spp and Ulvaria sp were found at several habitats. Their zoospore could be fixed in organic and inorganic materials and they generated blades more than $20 \mathrm{~cm}$. The natural blades of $U$. lactuca and $U$. fasciata were more rigid than Ulvaria oxysperma blades. This characteristic was attributed to the number of strata of cells in transversal section. Ulva spp had two while Ulvaria sp had only one. The blade color was modified during dry operation from light green to dark-green. The dried blade of algae produced rigid texture, as it was a fiber material. Final physical aspects, color and texture, did not change for more than 12 months. The color of dried blade of algae changed brown or light brown on heating above $60^{\circ} \mathrm{C}$.

\section{2 - Cultivation of Ulvaria oxysperma}

Cotton-nylon net was a good substrate to $U$. oxysperma. Enteromorpha sp growth in little quantity in the extreme of net. The density of algae was as high as compared to natural substrate. There were not significant predators. Alternate exposition or immersion of algae was important for the development of $U$. oxysperma. On the other hand, impetuous movement resulted breaking and loosing of algae. Texture of cultivated algae was similar to the natural algae, although the colour was dark green.

\section{3 - Chemical Composition}

The main nutritional components to different algae and $U$. oxysperma from two regions of harvest were determined. The content of humidity, ash, proteins, lipids, fibers and carbohydrate were determinated for Ulvaria oxysperma, Ulva lactuca and Ulva fasciata (Tables 1 and 2). These algae dried in darkness remained with a residual humidity between 15.6 and $20.4 \%$, which was sufficient to avoid the development of microorganisms. Ash levels of $U$. oxysperma from Guaraqueçaba were from 16.8\% (February, 1996) to $18.9 \%$ (November, 1995), slightly lower than Ilha do Mel, from 22.1\% (February, 1996) to $31.2 \%$ (November, 1995).

The average contents of organic material of $U$. oxysperma from Guaraqueçaba was higher $(82.1 \%)$ than Ilha do Mel (73.3\%). Protein was $6.3 \%$, except in the sample harvested in February 1996 from Ilha do Mel (10.0\%). Lipids were between 0.5 and $3.3 \%$. Fibers contents from Guaraqueçaba was lower (3.8\%) than from Ilha do Mel (10.3\%).

Table 1 - Chemical $^{* 1}$ composition of Ulvaria oxysperma (U.o.) harvested in November (n), 1995 and in February (f), 1996 from Guaraqueçaba (G) and from Ilha do Mel (IM) to $100 \mathrm{~g}$ in sample.

\begin{tabular}{lc|c|c|c}
\hline Contents & U.o.Gn & U.o.Gf & U.o.IMn & U.o.IMf \\
\hline humidity, g ${ }^{2}$ & 15.58 & 17.53 & 20.42 & 16.79 \\
ash, g & 18.91 & 16.83 & 22.14 & 31.22 \\
organic material, g \# & 81.09 & 83.17 & 77.86 & 68.78 \\
protein, g ${ }^{\#}$ & 6.03 & 6.39 & 6.51 & 10.02 \\
lipids, g & 0.89 & 1.44 & 3.28 & 0.53 \\
fibers, g & 4.60 & 3.06 & 8.95 & 11.73 \\
carbohydrates, g \# & 69.58 & 72.28 & 59.12 & 46.50 \\
calories levels, kcal ${ }^{* 2}$ & 262.07 & 270.23 & 232.41 & 192.08 \\
${ }^{* 1}$ Average of two repetitions. & & &
\end{tabular}


Algae from Ilha do Mel showed lower carbohydrate contents $(52.8 \%)$ than from Guaraqueçaba (70.9\%). Ulvaria oxysperma from Guaraqueçaba showed higher nutritional energy level $\left(266.2 \mathrm{kcal} 100 \mathrm{~g}^{-1}\right)$ than from Ilha do Mel $\left(212.2 \mathrm{kcal} 100 \mathrm{~g}^{-1}\right)$.

Table 2 showed that Ulva spp maintained a residual humidity from 15.1 to $20.8 \%$, similar to Ulvaria oxysperma (15.6 to 20.4). The development of microorganisms was not observed to storage in this grade and the coloration was also similar to $U$. oxysperma. Algae harvested from the Ilha do Mel demonstrated higher residual humidity than from Guaraqueçaba. Ash contents from Ulva lactuca (12.9\%) was lower than Ulva fasciata (19.8\%). Algae from Ilha do Mel showed ash level higher than algae from Guaraqueçaba.

Table 2 - Chemical composition from Ulva lactuca (U.l.) collected in Guaraqueçaba (G) in October (o), 1995 and in February (f), 1996 and from Ulva fasciata (U.f.) collected in the Ilha do Mel (IM) in December (d), 1995 and in February (f), $1996^{* 1}$ to $100 \mathrm{~g}$ sample.

\begin{tabular}{lc|c|c|c}
\multicolumn{1}{c}{ Contents } & U.l.Go & U.l.Gf & U.f.IMd & U.f.IMf \\
\hline humidity, g $^{* 2}$ & 18.08 & 15.09 & 20.80 & 18.64 \\
ash, g $^{\text {organic material, g }}{ }^{\#}$ & 13.23 & 12.54 & 20.61 & 17.75 \\
protein, g & 86.77 & 87.46 & 79.39 & 82.25 \\
lipids, g & 15.23 & 18.35 & 13.30 & 16.13 \\
fibers, g & 1.22 & 1.79 & 1.94 & 0.34 \\
Carbohydrates, g $^{\#}$ & 11.91 & 9.65 & 10.85 & 9.32 \\
calories levels, kcal $^{* 2}$ & 58.40 & 57.67 & 53.31 & 56.47 \\
\hline *1 Average & 250.28 & 271.88 & 224.86 & 238.76 \\
\hline
\end{tabular}

*1 Average of two repetitions.

*2 wet base.

\# dry base.

Organic matter in Ulva lactuca from Guaraqueçaba was higher $(87.1 \%)$ than Ilha do Mel (80.9\%). Protein from Ulva lactuca was slightly higher $(16.8 \%)$ than Ulva fasciata $(14.7 \%)$. Lipids were between 0.3 and $1.9 \%$, but without a characteristic behavior. Fibers from Ulva spp was between $9.3 \%$ and $11.9 \%$, which was similar to Ulvaria oxysperma from Ilha do Mel $(10.3 \%)$, but higher than $U$. oxysperma from Guaraqueçaba (3.8\%). Carbohydrate in Ulva lactuca $(58.0 \%)$ and Ulva fasciata $(54.9 \%)$ were similar to $U$. oxysperma from Ilha do Mel (52.8\%) and lower than $U$. oxysperma from Guaraqueçaba (70.9\%). Ulva lactuca showed energy content (261.1 kcal.100g $\mathrm{g}^{-1}$ ) higher than Ulva fasciata (231.8 kcal.100g $\mathrm{g}^{-1}$ ). This was similar to $U$. oxysperma from Guaraqueçaba (266.2) in comparison to Ilha do Mel $\left(212.2 \mathrm{kcal} 100 \mathrm{~g}^{-1}\right)$.

Table 3 shows chemical composition of commercial algae, called Urashima, sold in Brazil in 1998 and cultivated $U$. oxysperma. The blades of commercial algae show format almost square $(18 \times 20 \mathrm{~cm})$. Algae are packaged in plastic bags and stamped, with a drain agent to maintain a low residual humidity $(9.2 \%)$. Ash content was low and organic was high. Protein was very low (3.3\%). Carbohydrate was high $(88.2 \%)$ and fibers was low $(0.8 \%)$. However, energy content was very high (348.7 kcal. $\left.100 \mathrm{~g}^{-1}\right)$.

Cultivated $U$. oxysperma showed similar values to chemical composition as compared with algae grown on natural substrate. Nutritional energy content is between 251 and $276 \mathrm{kcal} 100 \mathrm{~g}^{-1}$. The high ash content suggested a good source of mineral and low calories product to reduce ingestion of high levels of energy; compared to commercial product.

Contents of protein, humidity and ash of other algae frequently found in mangroves, in mud or in trunks from coast of the Paraná were also measured (see Table 4). Protein contents (16.6 to $24.8 \%$ ) of Rhodophyta and Phaeophyta were frequently higher than Chlorophyta (6.0 to $18.4 \%$ ). On the other hand, humidity contents (14.2 to $20.8 \%)$ and (4.3 to $18.7 \%)$ were similar. Carbohydrate and protein ratio were different. 
Table 3 - Chemical composition of a commercial alga sold in Brazil and cultivated algae to 100g sample.

\begin{tabular}{|c|c|c|}
\hline Contents & cultivated $U$. oxysperma & commercial $^{* 1}$ \\
\hline humidity, $g^{* 2}$ & $15.4-18.8$ & 9.24 \\
\hline ash, $g$ \# & $15.4-17.8$ & 5.87 \\
\hline organic material, $\mathrm{g} \#$ & $77.9-85.0$ & 94.13 \\
\hline protein, $\mathrm{g}^{\#}$ & $5.9-11.7$ & 3.27 \\
\hline lipids, g\# & $0.5-1.1$ & 2.15 \\
\hline fibers, $g$ \# & $3.16-6.3$ & 0.76 \\
\hline carbohydrates, $\mathrm{g} \#$ & $67.0-59.9$ & 88.24 \\
\hline calories levels, kcal $* 2$ & $251-276$ & 348.7 \\
\hline
\end{tabular}

\footnotetext{
${ }^{\pi 1}$ Urashima, Chlorophyta algae in blades with $18 \times 20 \mathrm{~cm}$ with soybean juice and sugar.

${ }^{* 2}$ wet base.

\# dry base.
}

Table 4 - Protein level, humidity and ash from several algae Rhodophyta and Phaeophyta from Paraná Coastline harvested in Ilha do Mel, Paranaguá District.

\begin{tabular}{l|c|c|c|c}
\hline \multicolumn{1}{c|}{ Algae } & Date & Protein, \% & Humidity, \% & Ash, \% \\
\hline Acanthophora spicifera & Apr 95 & 17.27 & 15.80 & 16.58 \\
Hypnea cervicornis & Apr 95 & 18.72 & 15.08 & 21.96 \\
Dictyota cervicornis & Apr 95 & 18.82 & 14.10 & 20.48 \\
Bostrychia montagney & Apr 95 & 24.77 & 15.95 & 16.18 \\
Bostrychia scorpioides & Sep 95 & 20.29 & 13.78 & 17.77 \\
Porphyra spiralis & Jul 95 & 16.56 & 14.25 & 12.17 \\
Gelidium floridanum & Feb 96 & 20.54 & 16.13 & 5.14 \\
\hline
\end{tabular}

\# dry base.

\section{CONCLUSIONS}

Analysis of the protein, ash, humidity and carbohydrate contents was evaluated to estimate the chemical composition of Chlorophyta. $U$. oxysperma and Ulva spp showed higher levels minerals and lower levels of calories. Dried product at room temperature and in the shadow could stored by several months without change its aspect. $U$. oxysperma presented lower protein levels than Ulva spp, but higher than the commercial alga Urashima, which demonstrated lower fibers. Low level in lipids showed that would be an excellent food to dietary.

Guaraqueçaba was the best option to commercial production of $U$. oxysperma. Residual humidity of algae (16 to 20\%) was not modified after 12 months in storage in plastic. Organic material (69\% to $87 \%$ ) and inorganic material $(13 \%$ to $31 \%$ ) demonstrated to be a food with low level calories and rich in minerals. U. oxysperma show lower protein levels (6 to 10\%) than Ulva lactuca and Ulva fasciata (13 to 18\%), but higher than the commercial alga (3\%).

\section{ACKNOWLEDGEMENTS}

Authors thank UFPR and FUNPAR for financial support.

\section{RESUMO}

A composição química de três espécies de Chlorophyta foi determinada. Ulva lactuca se desenvolve em Guaraqueçaba e Ulva fasciata na Ilha do Mel, enquanto que Ulvaria oxysperma se desenvolve nos dois ecossistemas. Umidade (16-20\%), cinzas (17-31\%, base seca), proteínas $(6-10 \%$ bs), lipídeos $(0,5-3.2 \%$ bs $)$, fibras (3-12\%bs) e carboidratos (46-72\%bs) para U.oxysperma correspondeu a $192-270 \mathrm{kcal}^{1} 100 \mathrm{~g}^{-1}$ (base úmida). U.lactuca (15-18\%bs) e U.fasciata (13-16\%bs) mostraram teores levemente maiores para a proteína, mas com conteúdos energéticos similares $\quad\left(250-272\right.$ e $225-239$ kcal.100 $\left.\mathrm{g}^{-1}\right)$, respectivamente. As folhas in natura de U.lactuca e de U.fasciata eram mais rígidas do que as de U.oxysperma. Outras algas nativas apresentaram teores de proteínas maiores. Ulvaria sp pode ser cultivada sobre redes, sem apresentar competição 
com outras algas ou ação significativa de predadores. Ulvaria sp cultivada apresentou composição química similar ao da Ulvaria sp crescida sobre substratos naturais. É essencial escolher um local protegido da ação destrutiva da maré.

\section{REFERENCES}

Arieli, A; Sklan, D. and Kissil, G. (1993), A note on the nutritive value of Ulva lactuca for ruminants. Animal Production, 57 : (2), 329-331.

Borges, C. R. S. (Coord.) (1992), Plano integrado de conservação para a região de Guaraqueçaba, Paraná, Brasil. Curitiba: SPVS. 1, 128.

Cordeiro-Marino, M.; Braga, M. R. A.; Fujii, M. T.; Guimaraes, S. M. P. B. and Mitsugi, E. M. (1993), Monostromatic green algae from Espírito Santo State, Brazil: life history, growth and reproduction in culture. Revista Brasileira de Biologia, 53, 285-293.

Guo, Z. and Matthieson, A. C. (1992), Physiological ecology of four ulvoid green algae. Botânica Marina, $35:$ (6), 523-533.

Hirata, H. and Kohirata, E. (1993), Culture of the sterile Ulva sp in a marine fish farm. Israeli. Journal of Aquaculture, 45 : (4), 164-168.

IPARDES (1990), Macrozoneamento da APA de Guaraqueçaba. Curitiba. 1, 254 pp.

Ivanova, V.; Rouseva, R.; Kolarova, M.; Serkedjieva, J.; Rachev, R. and Manolova. (1994), Isolation of a polysaccharide with antiviral effect from Ulva lactuca. Preparative Biochemistry, 24 : (2), 83-97.

Jarrouj, M. (1992), Determinação da proteína presente na alga Rhodophyta "Bostrychia montagnei" Harvey. Monografia, (Bacharelado em Biologia), Pontifícia Universidade Católica do Paraná, Curitiba, Brazil. 36 pp.

Joly, A. B. (1965), Flora marinha do litoral do norte do Estado de São Paulo e regiões circunvizinhas. São Paulo: Universidade de São Paulo, São Paulo, Brazil. 267 pp.

Joly, A. B. (1957), Contribuição ao conhecimento da flora ficológica marinha da Baia de Santos $e$ arredores. São Paulo Universidade de São Paulo, São Paulo, Brazil. 197 pp.

Kapraun, D. F. and Sherman, S. G. (1989), Strain selection and cell isolation of Ulvaria oxysperma (Kutz.) Bliding - Chlorophyta for net cultivation. Hydrobiologia, 179 : (1), 53-60.

Lahaye, M. (1991), Marine algae as sources of fibers: Determination of soluble and insoluble dietary fiber contents in some "sea vegetables". Journal of the Science of Food and Agriculture, 54 : (4), 587-594.
Lahaye, M. and Axelos, M. A. V. (1993), Gelling properties of water-soluble polysaccharides from proliferating marine green seaweeds (Ulva spp). Carbohydrate Polymers., 22, 261-265.

Mahasneh, I; Jamal, M; Kashashneh, M. and Zibdeh, M. (1995) Antibiotic activity of marine algae against multi-antibiotic resistant bacteria. Microbios. 83 : (334), 23-26.

Miller, I. J. and Blunt, J. W. (2000), New ${ }^{13} \mathrm{C}$ NMR methods for determining the structure of algal polysaccharides. Part 3. The structure of the polysaccharide from Cladhymenia ablongifolia. Botanica Marina, 43, 263-271.

Naidu, K. A.; Tewari, A.; Joshi, H. V.; Viswanath, S.; Remesh, H. P. and Rao, S. V. (1993), Evaluation of nutritional quality and food. Safety of seaweeds of India.. J. Food Saf., 13 : (2), 17-90.

Pal, D.; Prakash, D. and Amla, D. V. (1998), Chemical composition of the green alga Botrycocus barunii. Cryptogamie, Algol., 19 : (4), 311-317.

Qasim, R. (1991), Amino Acid composition of some common seaweeds. Pakistan Journal of Pharmaceutical Sciencies., 4, 49-59.

Serot, T.; Courcoux, P. and Guillemineau, F. (1994), Extraction and partial characterization of protein from the green algae Ulva sp. Sciences des Aliments, 14 : (3), 301-309.

Shirata, M. T. (1993), Algas marinhas bentônicas do manguesal de Guaraqueçaba, Município de Guaraqueçaba, Estado do Paraná, Brasil. Estudos de Biologia, 3 : (35), 5-9.

Soares, C. R. (1990), Natureza dos sedimentos da superfície de fundos das baías das Laranjeiras e de Guaraqueçaba - complexo estuarino da Baía de Paranaguá (Estado do Paraná, Brasil). Rio Claro. Dissertação de Mestrado, Curso de Pós-Graduação em Geociências, Universidade Estadual de São Paulo. São Paulo, Brasil. 137 pp.

Ugadim, Y. (1973), Algas marinhas bentônicas do litoral Sul do Estado do Paraná. I Divisão Chlorophyta. Boletim de Botânica, 1, 11-77.

Yokoyama, M. Y and Guimarães, O. (1975), Determinação dos teores de $\mathrm{Na}, \mathrm{K}, \mathrm{O}$ e proteínas em algas marinhas. Acta Biológica Paranaense, 4 : (1/2), 19-24.

Received: May 09, 20023; Revised: March 11, 2003; Accepted: October 10, 2003. 